\title{
Unethical practices within medical research and publication - An exploratory study
}

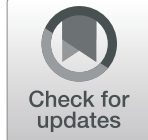

\author{
S. D. Sivasubramaniam ${ }^{1 *}$, M. Cosentino ${ }^{2}$, L. Ribeiro ${ }^{3}$ and F. Marino ${ }^{2}$
}

\author{
* Correspondence: s. \\ sivasubramaniam@derby.ac.uk \\ ${ }^{1}$ School of Human Sciences, \\ University of Derby, Derby DE22 \\ $1 G B, U K$ \\ Full list of author information is \\ available at the end of the article
}

\begin{abstract}
The data produced by the scientific community impacts on academia, clinicians, and the general public; therefore, the scientific community and other regulatory bodies have been focussing on ethical codes of conduct. Despite the measures taken by several research councils, unethical research, publishing and/or reviewing behaviours still take place. This exploratory study considers some of the current unethical practices and the reasons behind them and explores the ways to discourage these within research and other professional disciplinary bodies. These interviews/ discussions with PhD students, technicians, and academics/principal investigators $(\mathrm{PIs})(\mathrm{N}=110)$ were conducted mostly in European higher education institutions including UK, Italy, Ireland, Portugal, Czech Republic and Netherlands. Through collegiate discussions, sharing experiences and by examining previously published/reported information, authors have identified several less reported behaviours. Some of these practices are mainly influenced either by the undue institutional expectations of research esteem or by changes in the journal review process. These malpractices can be divided in two categories relating to (a) methodological malpractices including data management, and (b) those that contravene publishing ethics. The former is mostly related to "committed bias", by which the author selectively uses the data to suit their own hypothesis, methodological malpractice relates to selection of out-dated protocols that are not suited to the intended work. Although these are usually unintentional, incidences of intentional manipulations have been reported to authors of this study. For example, carrying out investigations without positive (or negative) controls; but including these from a previous study. Other methodological malpractices include unfair repetitions to gain statistical significance, or retrospective ethical approvals. In contrast, the publication related malpractices such as authorship malpractices, ethical clearance irregularities have also been reported. The findings also suggest a globalised approach with clear punitive measures for offenders is needed to tackle this problem.
\end{abstract}

Keywords: Medical research, Research misconduct, Committed bias, Unethical practices 


\section{Introduction}

Scientific research depends on effectively planned, innovative investigation coupled with truthful, critically analysed reporting. The research findings impact on academia, clinicians, and the general public, but the scientific community is usually expected to "self-regulate", focussing on ethical codes of conduct (or behaviour). The concept of self-regulation is built-in from the early stages of research grant application until the submission of the manuscripts for gaining impact. However, increasing demands on research esteem, coupled with the way this is captured/assessed, has created a relentless pressure to publish at all costs; this has resulted in several scientific misconduct (Rawat and Meena 2014). Since the beginning of this century, cases of blatant scientific misconduct have received significant attention. For example, questionable research practices (QRP) have been exposed by whistle blowers within the scientific community and publicised by the media (Altman 2006; John et al. 2012). Moreover, organisations such as the Centre for Scientific Integrity (CSI) concentrate on the transparency, integrity and reproducibility of published data, and promote best practices (www1 n.d.). These measures focus on "scholarly conduct" and promote ethical behaviour in research and the way it is reported/disseminated, yet the number of misconduct and/or QRP's are on the rise. In 2008, a survey amongst researchers funded by the National Institutes of Health (NIH) suggested there might be as many as 1,000 cases of potential scientific misconduct going unreported each year (Titus et al. 2008). Another report on bioRxiv (an open access pre-print repository) showed 6\% of the papers (59 out of 960) published in one journal (Molecular and Cellular Biology - MCB), between 2009 and 2016, contained inappropriately duplicated images (Bik et al. 2018). Brainard (2018) recently reported that the number of articles retracted by scientific journals had increased 10fold in the past 10 years. If the reported incidence of scientific misconduct is this high, then one can predict the prevalence of other, unreported forms of misconduct. The World Association of Medical Editors (WAME) has identified the following as the most reported misconduct: fabrication, falsification, plagiarism/ghost writing, image/data manipulation, improprieties of authorship, misappropriation of the ideas of others, violation of local and international regulations (including animal/human rights and ethics), inappropriate/false reporting (i.e. wrongful whistle-blowing) (www2 n.d.).

However, WAME failed to identify other forms of scientific misconduct, such as; reviewer bias (including reviewers' own scientific, religious or political beliefs) (Adler and Stayer 2017), conflicts of interests (Bero 2017), and peer-review fixing, which is widespread, especially after the introduction of author appointed peer reviewers (Ferguson et al., 2014; Thomas 2018). The most recent Retraction Watch report has shown that more than 500 published manuscripts have been retracted due to peer-review fixing; many of these are from a small group of authors (cited in Meadows 2017). Other reasons for retraction include intentional/unintentional misconduct, fraud and to a lesser extent honest errors. According to Fang et al. (2012), in a detailed study using 2,047 retracted articles within biomedical and life-sciences, $67.4 \%$ of retractions were due to some form of misconduct (including fraud/suspected fraud, duplicate publication, and plagiarism). Only $21.3 \%$ of retractions were due to genuine error. As can be seen, most of the information regarding academic misconduct is reported, detected or metaanalysed from databases. As for reporting (or whistle blowing), many scientists have shown been reticent to raise concerns, mainly because of the fear of aftermath or 
implications of doing so (Bouter and Hendrix 2017). An anonymous informationgathering activity amongst scientists, junior scientists, technicians and PhD students may highlight the misconduct issues that are being encountered in their day-to-day laboratory, and scholarly, activities. Therefore, this exploratory study of an interviewbased study reports potentially un-divulged misconduct and tries to form a link with previously reported misconduct that are either being enforced, practiced or discussed within scientific communities.

\section{Methodology}

This qualitative exploratory study was based on informal mini-interviews conducted through collegiate discussions with technicians, PhD scholars, and fellow academics $(\mathrm{N}=110)$ within medical and biomedical sciences mainly in European higher education institutions including UK, Italy, Ireland, Portugal, Czech Republic and Netherlands (only $5 \mathrm{PhD}$ students). PhD students $(\mathrm{n}=75)$, technicians (mostly in the UK; $\mathrm{n}=25$ ) and academics/principal investigators (PIs; $\mathrm{n}=10$ ), around Europe, have taken part in this qualitative narrative exploration study. These mini-interviews were carried out in accordance with local ethical guidance and processes. The discussions or conversations were not voice recorded; nor the details of interviewees taken to maintain anonymity. The data was captured (in long-hand) by summarising their views on following three questions (see below).

These answers/notes were then grouped according to their similarities and summarised (see Tables 1 and 2). The mini-interviews were semi-structured, based around three questions.

- Have you encountered any individual or institutional malpractices in your research area/laboratory?

- If so, could you give a short description of this misconduct?

- What are the measures, in your opinion, needed to minimise or remove these misconduct?

we also examined recently published and/or reported (in media) unethical practice or misconduct to compare our findings (see Table 2). Fig. 1 summarises the methodology and its meta-cognitive reflection (similar to Eaton et al. 2019).

\section{Results and discussion}

As stated above, this manuscript is an exploratory study of unethical practice amongst medical researchers that are not well known or previously reported. Hence, the methodology applied was more exploratory with minimal focus on standardisation, using details of qualitative approach and paradigm, or the impact of researcher characteristics and reflexivity (British Medical Journal (BMJ) - www3 n.d.). Most importantly, our initial informal meetings prior to this study clearly indicated that the participants were reluctant to provide information that would assist for an analysis linked to researcher characteristics and/or reflexivity. Thus, the level of data presented herein would not be suitable for a full thematic analysis. We do accept this as a research limitation.

This study has identified some less reported (not well-known) unethical behaviours or misconduct. These findings from technician/PhD scholars and academics/PIs are 
Table 1 Potential laboratory based misconduct

\begin{tabular}{|c|c|c|}
\hline Misconduct & Details & Individuals involved \\
\hline Replicates without borders $^{a}$ & $\begin{array}{l}\text { Constantly repeating experiments } \\
\text { until the data becomes statistical } \\
\text { significance }\end{array}$ & PhD students \\
\hline Confirmed negative controls ${ }^{\mathrm{a}}$ & $\begin{array}{l}\text { The use of a neutral substance } \\
\text { that is known to have no effects } \\
\text { in the experiment to ensure } \\
\text { negative results. }\end{array}$ & $\begin{array}{l}\text { PhD students and Post- } \\
\text { doctoral researchers }\end{array}$ \\
\hline Universal Positive contro ${ }^{a}$ & $\begin{array}{l}\text { Reusing previously produced } \\
\text { positive control for new } \\
\text { experiments }\end{array}$ & $\begin{array}{l}\text { PhD students, Post-doctoral } \\
\text { researchers and academics }\end{array}$ \\
\hline Ghost repeats $^{\mathrm{a}}$ & $\begin{array}{l}\text { Using results from the same } \\
\text { experiment as results of repeated } \\
\text { experiments. }\end{array}$ & PhD students \\
\hline Data mining ${ }^{a}$ & $\begin{array}{l}\text { Stealing others' ideas/data stored } \\
\text { in laboratory computers }\end{array}$ & Post-doctoral researchers \\
\hline Image manipulation & $\begin{array}{l}\text { Manipulating images to suit the } \\
\text { hypothesis (or to show } \\
\text { significance) }\end{array}$ & $\begin{array}{l}\text { PhD students and post- } \\
\text { doctoral researchers }\end{array}$ \\
\hline Selective usage $e^{a}$ & $\begin{array}{l}\text { Ignoring data/information that } \\
\text { would reduce significance (or } \\
\text { disprove hypothesis) }\end{array}$ & PhD students \\
\hline Ignoring contamination & $\begin{array}{l}\text { Purposely ignoring contamination } \\
\text { as the data effectively proves the } \\
\text { hypothesis }\end{array}$ & PhD students \\
\hline $\begin{array}{l}\text { Not following health \& } \\
\text { safety }(H \& S) \text { regulations }\end{array}$ & $\begin{array}{l}\text { Failing to carry out H\&S checks, } \\
\text { avoid producing own H\&S data } \\
\text { sheets and/or using the data } \\
\text { sheets produced by others } \\
\text { (without understanding the risk } \\
\text { or aversion measures) }\end{array}$ & $\begin{array}{l}\text { PhD students, post-doctoral } \\
\text { researchers and academics/ } \\
\text { Pls }\end{array}$ \\
\hline
\end{tabular}

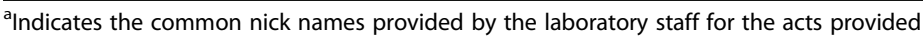

summarised in Tables 1 and 2 . The study initially aimed to identify any previously unreported unethical research conducts, however, the data shows that many previously identified misconduct are still common amongst researchers. Since the interviews were not audio recorded (to reassure anonymity), the participants were openly reported the unethical practices within their laboratories (or elsewhere). This may cast doubts on the accuracy of data interpretation. To minimise this, we have captured the summary of the conversation in long-hand.

We were able to generalise two emerging themes linked to the periods of a typical research cycle (as described by Hevner 2007); (a) methodological malpractices (including data management), and (b) those that contravene publishing ethics. Researcher-linked behaviours happen during laboratory investigation stage, where researchers employ questionable research practices, these include self-imposed as well as acquired (or taught) habits. As can be seen from Tables 1 and 2, these misconduct are mainly carried out by either $\mathrm{PhD}$ scholars, post-doctoral scientists or early career researchers. These reported "practices" may be common amongst laboratory staff, especially given the fact that some of these practices have been nicknamed (e.g. ghost repeats, data mining etc. - see Table 1). Individual or researcher-linked unethical behaviours mostly related to "committed bias", by which the researcher selectively uses the data to suit their own hypothesis or what they perceive as ground-breaking. This often results in conducts where research (and in some cases data/results) is statistically manipulated to suit the perceived conclusion. 
Table 2 Potential publication related misconduct

\begin{tabular}{|c|c|c|}
\hline Misconduct & Details & Individuals involved \\
\hline Convenient ethical clearance & $\begin{array}{l}\text { 1. Ambiguous details in ethical application } \\
\text { with room for varied interpretation about } \\
\text { study details. } \\
\text { 2. Backdated ethical approval, after the study }\end{array}$ & $\begin{array}{l}\text { Usually at the institutional } \\
\text { or departmental level. }\end{array}$ \\
\hline Selective use of data & $\begin{array}{l}\text { Deliberately ignoring or hiding findings to } \\
\text { enhance impact of the publication }\end{array}$ & Academics and Pls \\
\hline $\begin{array}{l}\text { Maximising mentorship } \\
\text { privileges }\end{array}$ & $\begin{array}{l}\text { Using junior academics to carry out or help in } \\
\text { expanding own research or offloading } \\
\text { teaching duties to mentees. }\end{array}$ & Pls and professors \\
\hline Authorship by demand & $\begin{array}{l}\text { Demanding authorship from mentees' work or } \\
\text { publications without any input into the } \\
\text { research }\end{array}$ & Pls and professors \\
\hline Authorship by default & $\begin{array}{l}\text { Expecting certain individuals (such as } \\
\text { professors, post-doctoral fellows) to have au- } \\
\text { thorships in every single manuscript produced } \\
\text { with a laboratory }\end{array}$ & $\begin{array}{l}\text { Mainly academics and } \\
\text { professors }\end{array}$ \\
\hline Malpractices in grant selection & $\begin{array}{l}\text { Selecting applications from mentees or } \\
\text { collaborators to offer internal funding }\end{array}$ & At institutional level \\
\hline Delaying review or decisions & $\begin{array}{l}\text { Purposely delaying reviewer decisions to } \\
\text { make sure their (reviewers) papers are } \\
\text { published first. }\end{array}$ & Established reviewers \\
\hline Reciprocal reviewing & $\begin{array}{l}\text { Agreement between academics to be a } \\
\text { "friendly" reviewer on manuscripts of each } \\
\text { other. }\end{array}$ & Established reviewers \\
\hline Indirect identification & $\begin{array}{l}\text { Authors purposely identifying themselves } \\
\text { within manuscript by quoting their previous } \\
\text { publications (by using terms as "Our previous } \\
\text { study has shown", paving the way to identify } \\
\text { them in the reference section) }\end{array}$ & $\begin{array}{l}\text { Amongst academics and } \\
\text { Pls }\end{array}$ \\
\hline
\end{tabular}

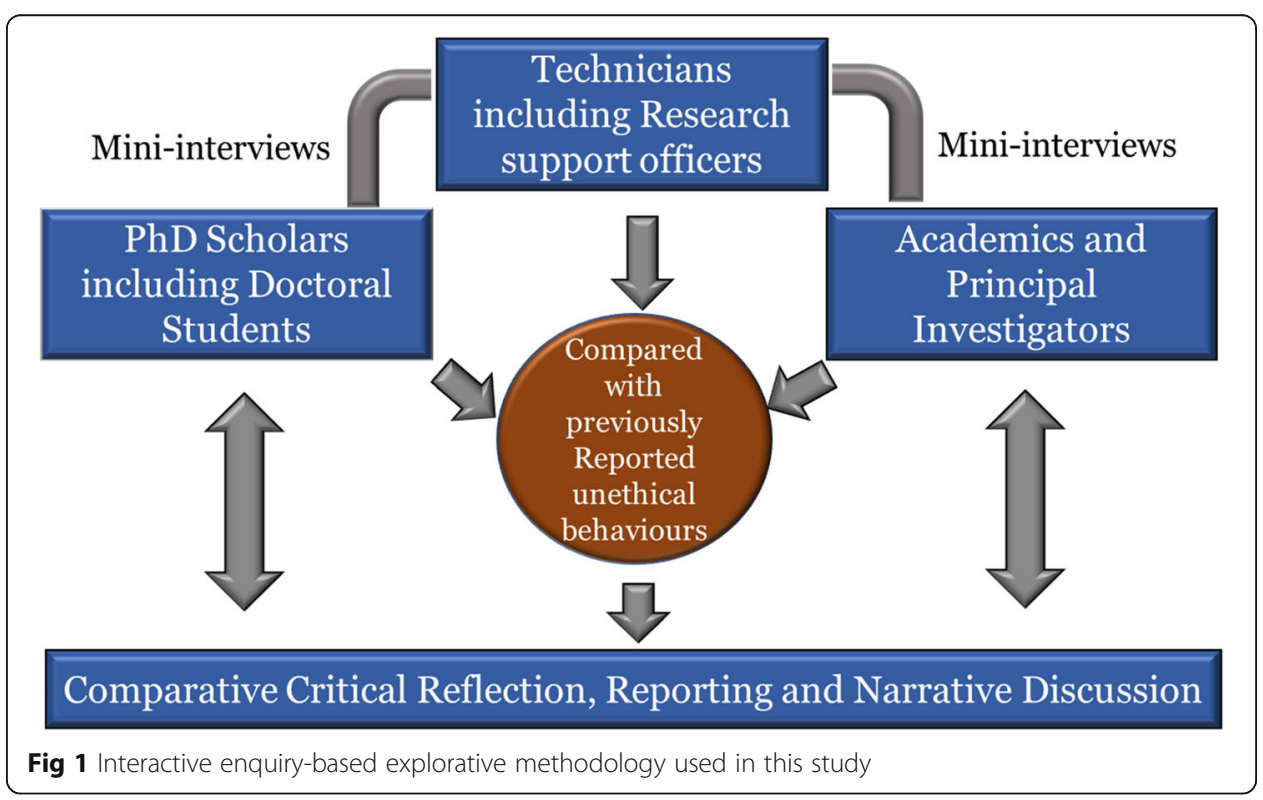


Although this is a small-scale pilot study, we feel this reflects the common trend in laboratory-based research. As mentioned earlier, although this study was set out to detect unreported research misconduct/malpractices, study participant reported some of the behaviours that were already reported in previous studies.

In contrast, established academics, professors and PIs tend to commit publicationrelated misconduct. These can be divided into author-related or reviewer-related misconduct. The former includes QRPs during manuscript preparation (such as selective usage of data, omitting outliers, improper ethical clearance, authorship demands etc). The latter is carried out by the academics when they review others manuscripts and includes delaying review decisions, reciprocal reviewing etc.

From tables above, it seems that most of the reported misconduct can be easily prevented if specific and accurate guidelines or code of conduct are present in each research laboratory (see below). This aspect, for example is of minor impact in the clinical research, where the study protocol is rigorously detailed in advance, the specific analysis that will be included in the final report specified in advance with clear primary or secondary endpoints, and all the analysis/reports need to be stored for the final study revision/conclusion. All these different steps are regulated by Good Clinical Practice guidelines (GCP; National Institute for Health Research Clinical Research Network (NIHR CRN- www4 n.d.).

This by no means indicates that in clinical research fraud does not exist, but that it is easier to discover it than in laboratory based-investigations. The paper of Verhagen et al. (2003) clearly refers to a specific situation that commonly happens in a research laboratory. The majority of experiments within biomedical research are conducted on tissues or cells. Therefore, the experimental set-ups, including negative and positive controls can easily (and frequently) be manipulated. This can only be prevented by using Standard Operating Procedures (SOP) and well written and clear regulation such as Good Laboratory Practice (GLP; Directive 2004/9/EC), and written protocols. However, at present, no such regulations exist apart from in industry-based research, where GLP is mandatory. In a survey-based systematic review, Fanelli (2009) reported that approximately $2 \%$ of scientists claimed they had fabricated their data, at some point in their research career. It is worth noting, Fanelli's study (as well as ours) only reported data from those who were willing admit engaging in these activities. This cast questions on actual number of occurrences, as many of them would not have reported misconduct. Other authors have highlighted the same issue and cast doubt on the reproducibility of scientific data (Resnik and Shamoo, 2017; Brall et al, 2017; Shamoo 2016; Collins and Tabak 2014; Kornfeld and Titus 2016).

\section{The interview responses}

We also wanted to understand the causes of these QRPs to obtain a clear picture of these misconduct. Based on interview responses, we have tried to give a narrative but critical description of individual perceptions, and their rationalisation in relation to previously published information.

\section{Methodological malpractices}

The data reported herein show that PhD scholars/post-doctoral fellows are mostly involved in laboratory-linked methodological misconduct. Many of them (especially the post-doctoral scientists) blamed supervisory/institutional pressures on not only 
enhancing publishing record, but also maintaining high impact. One post-doctoral scientist claimed "there is always a constant pressure on publication; my supervisor said the reason you are not producing any meaningful data is because you are a perfectionist". He further recalled his supervisor once saying "if the data is $80 \%$ correct, you should accept it as valid and stop repeating until you are satisfied".

Likewise, another researcher who recently returned from the US said "I was an excellent researcher here (home country), but when I went to America, they demanded at least one paper every six months". "When I was unable to deliver this (and missed a year without publishing any papers), my supervisor stopped meeting me, I was not invited for any laboratory meetings, presentations, and proposal discussions; in fact, they made me quit the job". A PhD student recalled his supervisor jokingly hinting "if you want a perfect negative control, use water it will not produce any results". Comments and demands like these must have played a big role in encouraging laboratory based misconduct. In particular, the pressure to publish more papers in a limited period led to misconduct such as data manipulation (removing outliers, duplicate replications, etc.) or changing the aim of the study, and as a consequence including data set that were not previously considered, because the results are not in line with the original aim of the study. All these aspects force the young researchers to adopt an attitude that leads them to obtain publishable results by any means (ethical or not) - A "Machiavellian personality trait" as put by Tijdink et al. (2016). Indeed, an immoral message is being delivered to these young researchers (future scientists), enhancing cheating behaviours. In fact, Buljan et al. (2018) have recently highlighted the research environment, in which a scientist is working, as one of the potential causes of misconduct.

\section{Behaviours that contravene publishing ethics}

Academics (and PIs) have mostly identified misconduct linked to contravening publishing ethics. This finding itself shows that most of the academics who took part in this study has less "presence" within their laboratories. When confronted with the data obtained from PhD scholars and technicians, some of them vehemently denied these claims. Others came up with a variety of excuses. One lecturer/researcher said, "I have got far too much teaching to be in my laboratory". Another professor said, "I have postdocs within my laboratory, they will look after the rest; to be honest, my research skills are too old to refresh!" One PI replied, "why should I check them? No one checked me when I was doing research". All these replies show a lack of care for research malpractices. It is true that academics are under pressure to deliver high impact research, carry out consultancy work, get involved with internationalisation within academia and teach (Edwards and Roy 2017). However, these pressures should not undermine research ethics.

One researcher claimed to have noticed at least two different versions of "convenient ethical clearance". According to him, some researchers, especially those using human tissues, avoid specifying their research aims; and instead write an application in such a way that they can use these samples for a variety of different projects (bearing in mind of possible future developments). For example, if they aim to use the tissue to study a particular protein, the ethical application would mention all the related proteins and linked pathways. They justify this by claiming the tissues are precious, therefore they 
are "maximising the effective use of available material". Whilst understanding the rationale within their argument, the academic who witnessed this practice asked a question "how ethical it is to supply misleading information in an ethical application?" He also highlighted issues with backdating ethical approval in one institution. That is, the ethical approval was obtained (or in his words "staged") after the study has been completed. Although this is one incident reported by one whistle-blower, it highlights the institutional malpractices.

Selective use of data is another category reported here and elsewhere (Priya Satalkar \& David Shaw, 2019; Blatt 2013; Bornmann 2013). One academic reported incidences of researchers purposely avoiding data to maximise the statistical significance. If this is the case, then the validity of reported work, its statistical significance, and in some cases its clinical usage are in question. What is interesting is that, as elegantly reported by Fanelli (2010), in the highest percentage of published papers, the findings always report the data that are in line with the original hypothesis. In fact, the number of papers published reporting negative results are very limited.

Misconduct relating to authorships have been highlighted in many previous studies (Ploug 2018; Vera-Badillo et al. 2016; Ng Chirk Jenn 2006). The British Medical Journal (BMJ - www5 n.d.) has classified two main types of misconduct relating to authorships; (a) omission of a collaborator who has contributed significantly to the project and (b) inclusion of an author who has not (or minimally) contributed. Interestingly in this study, one academic claimed that he was under pressure to include the research coordinator of his department as an author in every publication.

He recalled the first instance when he was pressurised to include the co-ordinator, "It was my first paper as a PI but due to my institutional policy, all potential publications needed to be scrutinised by the co-ordinator for their worthiness of publication", "so when I submitted for internal scrutiny, I was called by the co-ordinator who simply said there is nothing wrong with this study, but one important name is missing in authors' list" (indirectly requesting her name to be included). Likewise, another PI said, "it is an unwritten institutional policy to include at least one professor on every publication". Yet another PI claimed, "this is common in my laboratory - all post-doctoral scientists would have a chance to be an author" "by this way we would build their research esteem". His justification for this was "many post-doctoral scientists spend a substantial amount of time mentoring other scientists and PhD students, therefore they deserve honorary authorships". Similar malpractices have also been highlighted by other authors (Vera-Badillo et al. 2016; Gøtzsche et al. 2007) but the worrying finding is that in many cases, the practice is institutionalised. With regards to authorships, according to the International Committee of Medical Journal Editors (ICMJE - www6 n.d.), authorships can only be given to those with (a) a substantial contribution (at least to a significant part of the investigation), (b) involvement in manuscript preparation including contribution to critical review. However, our discussions have revealed complementary authorships, authorship denial, etc.

\section{Malpractices in peer-review process}

The final QRP highlighted by our interviewees relates to the vreviewing process. One academic openly admitted, "I and Dr X usually use each other as reviewers because we 
both understand our research", he further added, "the blind reviewing is the thing of the past, every author has his own writing style, and if you are in one particular research field, with time, you would be able to predict the origin of the manuscript you are reviewing (whether it is your friend or a person with a conflicting research interest!". Another academic said that "the era of blind reviewing is long gone, authors are intentionally or unintentionally identifying themselves within the manuscripts with sentences such as 'previously we have shown'. "This allows the reviewer to identify the authors from the reference list". He further claimed he also experienced reviewers intentionally delaying acceptance or asking for further experiments to be carried out, simply because they wanted their manuscript (on a related topic) to be published first! Incidences like this, though minimal, cast questions on the reviewing process itself.

Recent reports by Thomas (2018) and Preston (2017) (see also Adler and Stayer 2017) have highlighted issues (or scams) such as an author reviewing his own manuscripts! Of course, many journals do not use the suggested reviewers; instead, they build a database of reviewers and randomly select appropriate reviewers. Still, it is not clear how robust this approach is in curtailing reviewer-based misconduct. Organisations such as Retraction Watch constantly pick up and report these malpractices, yet there are no definite sanctions or punishment for the culprits (Zimmerman 2017)

One of the academic interviewees recalled an incidence in which an author has been dismissed due to a serious image manipulation scam, yet obtained a research tenure in another institution within 3 months of dismissal. Galbraith (2017) reviewed summaries of 284 integrity-related cases published by the Office of Research Integrity (ORI), and found that in around $47 \%$ of cases the researchers received moderate punishment and were often permitted to continue their research. This highlights the need for a globalised approach with clear sanction measures to tackle research misconduct. Although this is a small-scale study, it has highlighted that despite measures taken by research regulatory bodies, the problem of misconduct is still there. The main problem behind this is "the lack of care" underpinned by pressures for esteem.

\section{Limitations}

This is an exploratory study with minimal focus on standardisation, using details of qualitative approach and paradigm, or the impact of researcher characteristics and reflexivity. Therefore, the level of data presented herein is not suited for a full thematic analysis. Also, this is a small-scale study with a sample size of of 110 participants who are further divided into sub-groups (such as PhD students, technicians and PIs). This limits the scope of analysing variability in the responses of individual sub-groups, and therefore might have resulted in voluntary response bias (i.e. responses are influenced by individual perceptions against research misconduct). Yet, the study has highlighted the issue of research misconduct is worth pursuing using a large sample. It also highlighted the common QRPs (both laboratory and publication related) that need to be focussed further, enabling us to establish a right research design for future studies.

\section{The way forward}

This exploratory study (and previously reported large scale studies) showed QRP is still a problem in science and medical research. So what are the way forward to stop these 
types of misconduct? Whilst it is important to set up confirmed criteria for individual research conduct, it is also important to set up institutional policies. These policies should aim at promoting academic/research integrity, with paramount attention on the training of young researchers about research integrity. The focus should be on young researchers attaining rigorous learning/application of the best methodological and professional standards in their research. In fact, the Singapore statement on research integrity (www7 n.d.), not only highlights the importance of individual researchers maintaining integrity in their research, but also insists the roles of institutions creating/ sustaining research integrity via educational programmes with continuous monitoring (Cosentino and Picozzi 2013). Considering the findings from this study, it would also be appropriate to suggest an international regulatory body to regularly monitor these practices involving all stakeholders including governments.

In fact, this (and other studies) have highlighted the importance of re-validating the "voluntary commitment" to follow the research integrity. With respect to individual researchers, we propose using a unified approach for early career researchers (ECRs). They should be educated about the importance of ethics/ethical behaviours (see Table 3) for our suggestion for ECRs). We feel it is vital to provide compulsory ethical training throughout their career (not just at the beginning). It is also advisable to regularly carry out "peer review" visits/processes between laboratories for ethical and health/safety aspects. Most importantly, it is time for the research community to move away from the expectation of "self-governance" establish and international research governance guidelines that can monitored by individual countries.

We, do agree this is a small-scale pilot study and due to the way it was conducted, we are unable to carry out a full thematic analysis. This was mainly because the participants were extremely reluctant to offer information to formulate researcher characteristics. Also, the study data in many cases conforms to the previously reported fact, that

Table 3 Recommendations for Early Career Researchers for ethical Research

\begin{tabular}{|c|c|c|}
\hline $\begin{array}{l}\text { Pre-investigatory } \\
\text { training phase }\end{array}$ & $\begin{array}{l}\text { Laboratory investigation } \\
\text { phase }\end{array}$ & Dissemination phase \\
\hline $\begin{array}{l}\text { Read around the } \\
\text { subject area, } \\
\text { methodologies (and } \\
\text { their potential flaws) }\end{array}$ & $\begin{array}{l}\text { Think about your own } \\
\text { research integrity. Do not let } \\
\text { others influence your morals }\end{array}$ & $\begin{array}{l}\text { Truthfully report what the } \\
\text { data show in relation to } \\
\text { hypothesis }\end{array}$ \\
\hline $\begin{array}{l}\text { Learn about ethical } \\
\text { principles and their } \\
\text { applications to prepare } \\
\text { your ethics application }\end{array}$ & $\begin{array}{l}\text { Avoid data manipulation, } \\
\text { selective usage, stealing results } \\
\text { from others tc. }\end{array}$ & $\begin{array}{l}\text { Defend your findings with } \\
\text { facts supported by critical } \\
\text { analysis }\end{array}$ \\
\hline $\begin{array}{l}\text { Prepare for ethical } \\
\text { application with power } \\
\text { calculations, statistics, } \\
\text { Gannt chart etc. }\end{array}$ & $\begin{array}{l}\text { Repeat to ascertain } \\
\text { reproducibility and always } \\
\text { consider outliers }\end{array}$ & $\begin{array}{l}\text { Avoid plagiarism, data } \\
\text { manipulation and/or data } \\
\text { recycling }\end{array}$ \\
\hline $\begin{array}{l}\text { Complete health and } \\
\text { safety course, risk } \\
\text { assessments and COSSH }\end{array}$ & $\begin{array}{l}\text { Be truthful and avoid } \\
\text { manipulation or selective } \\
\text { usage }\end{array}$ & $\begin{array}{l}\text { Accept the shortcomings and } \\
\text { discuss future directions }\end{array}$ \\
\hline $\begin{array}{l}\text { Build a meaningful } \\
\text { working relationship } \\
\text { with your supervisor/ } \\
\text { guide }\end{array}$ & $\begin{array}{l}\text { Record all the findings for } \\
\text { future reference and analysis }\end{array}$ & $\begin{array}{l}\text { Answer/address reviewers } \\
\text { questions with integrity }\end{array}$ \\
\hline $\begin{array}{l}\text { Acquire the necessary } \\
\text { technical knowledge } \\
\text { and train yourself }\end{array}$ & $\begin{array}{l}\text { Challenge your findings by } \\
\text { critical analysis }\end{array}$ & $\begin{array}{l}\text { Accept the methodological } \\
\text { flaws and address the issues } \\
\text { highlighted by the reviewers }\end{array}$ \\
\hline
\end{tabular}


QRP and research misconduct is still a problem within science and medicine. Yet, this study has attempted to narrate the previously unreported justifications given by the interviewees. In addition, we were able to highlight that these activities are becoming regular occurrence (those nick-named behaviours). We also provided some directives on how academic pressures are inflicted upon early career researchers. We also provided some recommendations in regard to the training ECRs.

\section{Significance}

The study has highlighted the negative influence on supervisory/peer pressures and/or inappropriate training may be main causes for these misconducts, highlighting the importance on devising and implementing a universal research code of conduct. Although this was an exploratory investigation, the data presented herein have pointed out that unethical practices can still be widespread within biomedical field. It highlighted the fact that despite the proactive/reflective measures taken by the research governance organisations, these practices are still going on in different countries within Europe. As the study being explorative, we had the flexibility to adapt and evolve our questions in reflection to the responses. This would help us to carry out a detailed systematic research in this topic involving international audience/researchers.

\section{Concluding remarks}

To summarise, this small-scale interview-based narrative study has highlighted that QRP and research misconduct is still a problem within science and medicine. Although they may be influenced by institutional and career-related pressures, these practices seriously undermine ethical standards, and question the validity of data that are being reported. The findings also suggest that both methodological and publication-related malpractices continue, despite being widely reported. The measures taken by journal editors and other regulatory bodies such as WAME and ICMJE may not be efficient to curtail these practices. Therefore, it would be important to take steps in providing a universal research code of conduct. Without a globalised approach with clear punitive measures for offenders, research misconduct and QRP not only affect reliability, reproducibility, and integrity of research, but also hinder the public trustworthiness for medical research. This study has also highlighted the importance of carrying out large-scale studies to obtain a clear picture about misconduct undermining research ethics culture.

\section{Acknowledgements}

Authors wish to thank the organising committee of the 5th international conference named plagiarism across Europe and beyond, in Vilnius, Lithuania for accepting this paper to be presented in the conference. We also sincerely thank Dr Carol Stalker, school of Psychology, University of Derby, for her critical advice on the statistical analysis.

\section{Authors' contributions}

Dr Sivasubramaniam has produced the questionnaire with interview format with the contribution of all other authors. He also has read the manuscript with the help of Prof Consentino. The latter also contributed for the initial literature survey and discussion. Drs Marino and Ribario have helped in the data collection and analysis. The author(s) read and approved the final manuscript. 


\section{Competing interests}

The authors can certify that they have NO affiliations with or involvement in any organization or entity with any financial or non-financial interests (including personal or professional relationships, affiliations, knowledge or beliefs) in the subject matter or materials discussed in this manuscript.

\section{Author details}

${ }^{1}$ School of Human Sciences, University of Derby, Derby DE22 1GB, UK. ${ }^{2}$ Center of Research in Medical Pharmacology, University of Insubria, Via Ravasi, 2, 21100 Varese, VA, Italy. ${ }^{3}$ Faculty of Medicine, University of Porto, Porto, Portugal.

Received: 17 July 2020 Accepted: 24 January 2021

Published online: 01 April 2021

\section{References}

Adler AC, Stayer SA (2017) Bias Among Peer Reviewers. JAMA. 318(8):755. https://doi.org/10.1001/jama.2017.9186

Altman, LK (2006). For science gatekeepers, a credibility gap. The New York Times. Retrieved from http://www.nytimes.com/2 006/05/02/health/02docs.html?pagewanted=all. Accessed 26 July 2019

Bero L (2017) Addressing Bias and Conflict of Interest Among Biomedical Researchers. JAMA 317(17):1723-1724. https://doi. org/10.1001/jama.2017.3854

Bik EM, Fang FC, Kullas AL, Davis RJ, Casadevall A (2018) Analysis and Correction of Inappropriate Image Duplication: the. Mol Cell Biol Exp. https://doi.org/10.1128/MCB.00309-18

Blatt M (2013) Manipulation and Misconduct in the Handling of Image Data. Plant Physiol 163(1):3-4. https://doi.org/10.1104/ pp.113.900471

Bornmann L (2013) Research Misconduct—Definitions, Manifestations and Extent. Publications. 1:87-98. https://doi.org/10. 3390/publications1030087

Bouter LM, Hendrix S (2017) Both whistle-blowers and the scientists they accuse are vulnerable and deserve protection. Account Res 24(6):359-366. https://doi.org/10.1080/08989621.2017.1327814

Brainard J (2018) Rethinking retractions. Science. 362(6413):390-393. https://doi.org/10.1126/science.362.6413.390

Brall C, Maeckelberghe E, Porz R, Makhoul J, Schröder-Bäck P (2017) Research Ethics 2.0: New Perspectives on norms, values, and integrity in genomic research in times of even ccarcer resources. Public Health Genomics 20:27-35. https://doi.org/ $10.1159 / 000462960$

Buljan I, Barać L, Marušić A (2018) How researchers perceive research misconduct in biomedicine and how they would prevent it: A qualitative study in a small scientific community. Account Res 25(4):220-238. https://doi.org/10.1080/ 08989621.2018 .1463162

Collins FS and Tabak LA (2014) Policy: NIH plans to enhance reproducibility. NATURE (Comment) - https://www.nature.com/ news/policy-nih-plans-to-enhance-reproducibility-1.14586

Cosentino M , and Picozzi M (2013) Transparency for each research article: Institutions must also be accountable for research integrity. BMJ 2013;347:f5477 doi: https://doi.org/10.1136/bmj.f5477.

Directive 2004/9/EC of the European Parliament and of the Council of 11 February 2004 on the inspection and verification of good laboratory practice (GLP). https://eur-lex.europa.eu/LexUriServ/LexUriServ.do?uri=OJ:L:2004:050:0028:0043:EN:PDF. Accessed 07 Sep 2019

Eaton SE, Chibry N, Toye MA, Toye MA, Rossi S (2019) Interinstitutional perspectives on contract cheating: a qualitative narrative exploration from Canada. Int J Educ Integr 15:9. https://doi.org/10.1007/s40979-019-0046-0

Edwards M, Roy (2017) Academic Research in the 21st Century: Maintaining Scientific Integrity in a Climate of Perverse Incentives and Hypercompetition. Environ Eng Sci 34(1):51-61. https://doi.org/10.1089/ees.2016.0223

Fanelli D (2009) How Many Scientists Fabricate and Falsify Research? A Systematic Review and Meta-Analysis of Survey Data. Plos One 4(5):e5738

Fanelli D (2010) Do Pressures to Publish Increase Scientists' Bias? An Empirical Support from US States Data. PLoS One 5(4): e10271. https://doi.org/10.1371/journal.pone.0010271

Fang FC, Steen RG, Casadevall A (2012) Misconduct accounts for the majority of retracted scientific publications. PNAS 109(42):17028-11703. https://doi.org/10.1073/pnas.1212247109

Ferguson C, Marcus A, Oransky I (2014) Publishing: Publishing: The peer-review scam. Nature (News review). 515(7528):480-2. http://www.nature.com/news/publishing-the-peer-review-scam-1.16400. Accessed 21 Nov 2019

Galbraith KL (2017) Life after research misconduct: Punishments and the pursuit of second chances. J Empir Res Hum Res Ethics 12(1):26-32. https://doi.org/10.1177/1556264616682568

Gøtzsche PC, Hróbjartsson A, Johansen HK, HaahrMT ADG, Chan A-W (2007) Ghost Authorship in Industry-Initiated Randomised Trial. Plos-Med. https://doi.org/10.1371/journal.pmed.0040019

Hevner AR (2007) A Three Cycle View of Design Science Research. Scand J Inf Syst 19(2):4 https://aisel.aisnet.org/sjis/vol19/ iss $2 / 4$

Jenn NC (2006) Common Ethical Issues In Research And Publication. Malays Fam Physician 1(2-3):74-76

John LK, Loewenstein G, Prelec D (2012) Measuring the prevalence of questionable research practices with incentives for truth telling. Psychol Sci. 23(5):524-532

Kornfeld DS, Titus SL (2016) (2016) Stop ignoring misconduct. Nature. 537(7618):29-30. https://doi.org/10.1038/537029a

Meadows, A. (2017). What does transparent peer review mean and why is it important? The Scholarly Kitchen, [blog of the Society for Scholarly Publishing.] [Google Scholar]

Ploug TJ (2018) Should all medical research be published? The moral responsibility of medical journal. Med Ethics 44:690-694

Preston A (2017) The future of peer review. Scie Am. Retrieved from https://blogs.scientificamerican.com/observations/thefuture-of-peer-review/

Rawat S, Meena S (2014) Publish or perish: Where are we heading? J Res Med Sci. 19(2):87-89

Resnik DB, Shamoo AE (2017) Reproducibility and Research Integrity. Account Res. 24(2):116-123. https://doi.org/10.1080/ 08989621.2016 .1257387 
Satalka P, Shaw D (2019) How do researchers acquire and develop notions of research integrity? A qualitative study among biomedical researchers in Switzerland. BMC Med Ethics 20:72. https://doi.org/10.1186/s12910-019-0410-x

Shamoo AE (2016) Audit of research data. Account Res. 23(1):1-3. https://doi.org/10.1080/08989621.2015.1096727

Thomas SP (2018) Current controversies regarding peer review in scholarly journals. Issues Ment Health Nurs 39(2):99-101. https://doi.org/10.1080/01612840.2018.1431443.

Tijdink JK, Bouter LM, Veldkamp CL, van de Ven PM, Wicherts JM, Smulders YM (2016) Personality traits are associated with research misbehavior in Dutch scientists: A cross-sectional study. Plos One. https://doi.org/10.1371/journal.pone.0163251

Titus SL, Wells JA, Rhoades LJ (2008) Repairing research integrity. Nature 453:980-982

Vera-Badillo, Marc Napoleonea FE, Krzyzanowskaa MK, Alibhaib SMH, Chanc A-W, Ocanad A, Templetone AJ, Serugaf B, Amira E, Tannocka IF, (2016) Honorary and ghost authorship in reports of randomised clinical trials in oncology. Eur I Cancer (66)1 doi: https://doi.org/10.1016/j.ejca.2016.06.023

Verhagen $H$, Aruoma Ol, van Delft JH, Dragsted LO, Ferguson LR, Knasmüller S, Pool-Zobel BL, Poulsen HE, Williamson G, Yannai S (2003) The 10 basic requirements for a scientific paper reporting antioxidant, antimutagenic or anticarcinogenic potential of test substances in in vitro experiments and animal studies in vivo. Food Chem Toxicol. 41(5):603-610

www1 n.d.: https://retractionwatch.com/the-center-for-scientific-integrity/. Accessed 13 Nov 2019

www2 n.d.: http://www.icmje.org/recommendations/browse/roles-and-responsibilities/defining-the-role-of-authors-andcontributors.html. Accessed 07 July 2019

www3 n.d.: https://bmjopen.bmj.com/content/bmjopen/8/12/e024499/DC1/embed/inline-supplementary-material-1. pdf?download=true. Accessed 26 July 2019

www4n.d.: http://www.crn.nihr.ac.uk/learning-development/ - National Institute for Health Research Clinical Research Network (NIHR CRN) - Accessed 13 Nov 2019

www5 n.d.: https://www.bmj.com/about-bmj/resources-authors/forms-policies-and-checklists/scientific-misconduct. Accessed 07 July 2019

www6 n.d.: http://www.icmje.org/recommendations/browse/roles-and-responsibilities/defining-the-role-of-authors-andcontributors.html - Accessed 0 July 2019

www7 n.d.: http://www.singaporestatement.org. Accessed 10 Aug 2019

Zimmerman SV (2017), "The Canadian Experience: A Response to 'Developing Standards for Research Practice: Some Issues for Consideration' by James Parry", Finding Common Ground: Consensus in Research Ethics Across the Social Sciences (Advances in Research Ethics and Integrity, Vol. 1) Emerald Publishing Limited, pp. 103-109. https://doi.org/10.1108/ S2398-601820170000001009

\section{Publisher's Note}

Springer Nature remains neutral with regard to jurisdictional claims in published maps and institutional affiliations.

Ready to submit your research? Choose BMC and benefit from:
- fast, convenient online submission
- thorough peer review by experienced researchers in your field
- rapid publication on acceptance
- support for research data, including large and complex data types
- gold Open Access which fosters wider collaboration and increased citations
- maximum visibility for your research: over 100M website views per year
At BMC, research is always in progress.
Learn more biomedcentral.com/submissions

